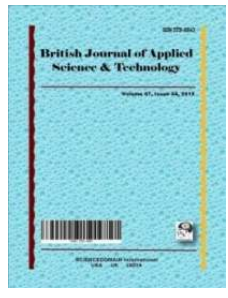

British Journal of Applied Science \& Technology

13(2): 1-10, 2016, Article no.BJAST.22565

ISSN: 2231-0843, NLM ID: 101664541

SCIENCEDOMAIN international

www.sciencedomain.org

\title{
Reliability of Back-Contact MWT Modules under Hot and Humid Conditions
}

\author{
F. Bandou', A. Hadj Arab ${ }^{1}$, M. S. Belkaid ${ }^{2}$, V. Rosca ${ }^{3}$, M. G. Guichoux ${ }^{3}$, \\ W. Eerenstein ${ }^{3}$, J. A. M. van Roosmalen ${ }^{3}$ and P. O. Logerais ${ }^{4^{*}}$ \\ ${ }^{1}$ Centre de Développement des Énergies Renouvelables (CDER), BP 62, Route de l'Observatoire \\ Bouzaréah, 16340 Algiers, Algeria. \\ ${ }^{2}$ Laboratoire des Technologies Avancées du Génie Electrique (LATAGE), Université Mouloud \\ Mammeri de Tizi-Ouzou (UMMTO), BP No17 RP, Tizi-Ou zou, Algeria. \\ ${ }^{3}$ ECN Solar Energy, P.O.Box 1, 1755 ZG Petten, The Netherlands. \\ ${ }^{4}$ Université Paris-Est, CERTES, IUT de Sénart, rue Georges Charpak, 77567 Lieusaint, France.
}

\section{Authors' contributions}

This work was undertaken in the context of the collaboration between CDER in Algeria and ECN in the Netherlands. Authors VR, MGG, WE and JAMVR from ECN solar energy carried out the protocol and the experimental results. Authors FB, AHA and MSB performed the analysis, the literature searches and the drafting of the manuscript. Author POL brought a critical view and improvements regarding the contents, clarity of the contribution and the layout of the paper. All authors have read and approved the final manuscript.

Article Information

DOI: 10.9734/BJAST/2016/22565 Editor(s):

(1) Rui Xiao, School of Energy and Environment, Southeast University, China. Reviewers:

(1) Abraham Dandoussou, University of Buea, Cameroon. (2) M. Jeevarani, Pondicherry University, India. Complete Peer review History: http://sciencedomain.org/review-history/12320

\author{
Original Research Article
}

Received $10^{\text {th }}$ October 2015

Accepted $4^{\text {th }}$ November 2015

Published $18^{\text {th }}$ November 2015

\begin{abstract}
Aims: Back-contact metallization-wrap-through (MWT) modules made with different materials were manufactured and tested at ECN in The Netherlands.

Study Design: Damp heat testing $\left(\mathrm{DH}, 8^{\circ} \mathrm{C}\right.$ and $85 \%$ relative humidity) was performed to investigate the effect of the module materials and potential failure mechanisms on electrical performance degradation.

Place and Duration of Study: ECN Solar Energy, P.O.Box 1, 1755 ZG Petten, Netherlands and Centre de Développement des Energies Renouvelables, Division Energie Solaire Photovoltaïque, Route de l'Observatoire, BP 62, Bouzaréah, 16340, Alger, Algeria, between June 2011 and March 2015.
\end{abstract}




\begin{abstract}
Methodology: Fourteen back-contact MWT modules with different combinations of four conductive backsheet foils (inner isolation layers, also referred to as inner layer dielectric, ILD), two electrically conductive adhesives (CA) and two encapsulants were tested.

Results: Results reveal that modules which combine conductive backsheet foil with two types of ILD and ethylene-vinyl-acetate (EVA) showed the highest degradation levels. It is suggested that effects of moisture in EVA cause a weakening of the adhesion strength at the ILD/Cu interface and then delamination between conductive adhesive and Ag-plated contacts applied to the copper interconnection foil. Removal of ILD significantly improves the stability of back-contact modules. Enhanced reliability is observed for modules which combine ILD-free foil Cu backsheet, conductive adhesive and polyolefin or EVA as encapsulant.

Conclusion: Removal of ILD is the most interesting approach and is currently adopted by foil manufacturers. Importantly, the modules built with ILD-free backsheet and either polyolefin encapsulant or EVA showed respectively only $0.3 \%$ and $1.6 \%$ maximum power loss after 2000 hours of damp heat which is well below the requirement of the IEC 61215 standard.
\end{abstract}

Keywords: Back-contact module; metallization wrap through cell; damp heat test; reliability.

\section{INTRODUCTION}

Commercial solar cell module manufacturers offer long-term product warranties in the range of 20-30 years. To ascertain long-term stability without actual field data, several accelerated tests are employed. An important tool in the qualification of solar cell modules is the Damp Heat (DH) test [1], where modules are placed in humidity and temperature controlled environment for extended exposure. According to the IEC 61215 standard [2], photovoltaic modules should not degrade by more than $5 \%$ in relative output power during 1000 hours at $85^{\circ} \mathrm{C}$ and $85 \%$ relative humidity (rh) to pass the $\mathrm{DH}$ test.

The metallization wrap through (MWT) technology developed by ECN Solar Energy (The Netherlands) is one of the most promising new technologies for achieving low-cost and highefficiency solar cell modules [3-5]. Standard crystalline silicon solar cells are interconnected front to rear by (tinned) copper wires in straight lines. In the MWT technology the solar cells are perforated with typically sixteen holes, in which the front side metallization is wrapped through to the back of the cell to form back contacts. The back-contact module technology allows a singlestep encapsulation and interconnection process of the back-contact cells. The main distinctive feature of this technology is the use of a full area conductive backsheet foil (typically copper) and a conductive adhesive to connect the cells electrically [6]. The full area conductive backsheet is patterned to interconnect both polarities of the solar cells and the cells can simply be picked and placed by a programmable robot, allowing large flexibility. Currently MWT modules are gaining increased interest from industry [7], namely because their efficiency can be up to $10 \%$ higher $[8,9]$. The main challenge for MWT modules is to demonstrate long-term stability comparable to or better than the existing technologies.

In the present study, MWT modules made with various combinations of materials were manufactured and tested under damp heat exposure with the aim of selecting the materials and packaging which offer the best stability under hot and humid conditions. In order to compare the results, measurements of electrical characteristics and visual controls were performed at specific times for the different samples. Obtained results are confronted and evolutions of performances are discussed.

\section{STRUCTURE OF PHOTOVOLTAIC MODULES}

The back-contact modules were manufactured at ECN $[4,10,11]$ (see Fig. 1a). Each module contains 60 cells. The module manufacturing process has been developed together with the Dutch equipment manufacturer Eurotron [4]. Fully automated production lines for manufacturing of back-contact modules are now commercially available. The main distinctive feature of this technology is the use of a patterned conductive backsheet foil and a conductive adhesive to make the electrical connection between the cells (see Fig. 1b). This back-contact module technology offers the advantage of up to $10 \%$ higher power conversion efficiency and lower yield loss by the low stress handling and interconnection technology; modules with cells down to $120 \mu \mathrm{m}$ thickness have been manufactured without cell breakage $[3,8,9,12]$. MWT modules have proved to be reliable in climatic chamber testing and IEC certification has been achieved by several parties [12-15]. 


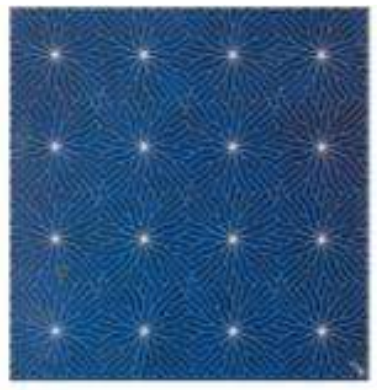

(a)

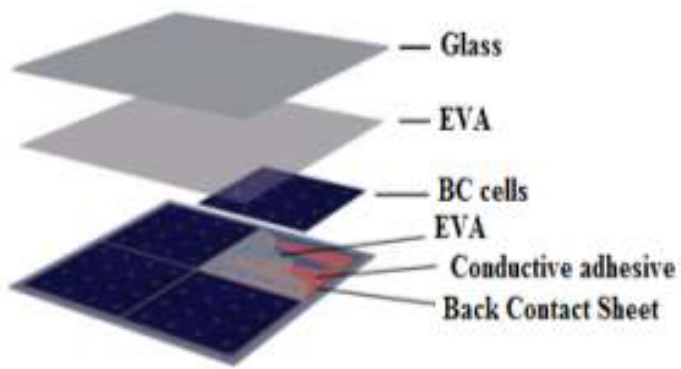

(b)

Fig. 1. (a) MWT cell, (b) Schematic of the build-up of a MWT module

\section{EXPERIMENTAL}

Fourteen modules were manufactured and tested at ECN with different constituting materials. They were introduced in a climatic chamber to test the compatibility between the various module components. The effect of damp heat has been investigated for the fourteen MWT modules made with different combinations of four conductive backsheet foils (inner layer dielectric ILD-1 and ILD-2, ILD-1 with an aluminium (AI) layer in the backsheet and no ILD), two encapsulants (ethylene-vinyl-acetate (EVA), polyolefin) and two electrical conductive adhesives (CA-1, CA-2). The polyolefin used releases no acetic acid upon degradation contrary to EVA. CA-1 was used in combination with foils with ILD-1. These foils have Ag-plated contacts applied to copper $(\mathrm{Cu})$. CA-2 was used in combination with foils without ILD and was applied directly on copper [15].

All the samples had the same type of multicrystalline silicon photovoltaic cells and glass. Table 1 describes the samples exposed to the $\mathrm{DH}$ test. Chamber tests at $85^{\circ} \mathrm{C}$ and $85 \%$ relative humidity for 2000 hours were performed. Visual inspections were realized at initial time, after 1000 hours and 2000 hours. Electrical performances of the short-circuit current $\mathrm{I}_{\mathrm{sc}}$, of the open-circuit voltage $V_{o c}$, of the maximum power $P_{\max }$ and of the fill factor FF were initially taken before and after exposure to 2000 hour DH test for the different samples of Table 1. Here damp heat tests were performed for a duration of 2000 hours which is twice the one required by IEC 61215 [2]. To check the performance of the modules during the test, these measurements were also performed after 1000 hours. The electrical performance of the modules was measured using a Class A solar simulator (Pasan SS3b) under Standard Test Conditions (STC) $\left(A M=1.5, G=1000 \mathrm{~W} / \mathrm{m}^{2}, T_{C}=25^{\circ} \mathrm{C}\right)$ in accordance with the IEC 60904-3 standard). The I-V curves are measured by applying an impulse voltage with a linear ramp to the terminals of the module within one flash of the solar simulator lamp. The measuring system error referring to the maximum power is relatively inferior to $3 \%$. The relative error for measuring $\mathrm{V}_{\mathrm{oc}}$ and $\mathrm{I}_{\mathrm{sc}}$ were $1.3 \%$ and $2.2 \%$ respectively.

\section{Table 1. Modules manufactured and tested}

\begin{tabular}{|c|c|c|c|}
\hline Module & $\begin{array}{l}\text { Foil//LD } \\
\text { type }\end{array}$ & $\begin{array}{l}\text { Conductive } \\
\text { adhesive }\end{array}$ & Encapsulant \\
\hline M01, M02 & ILD-1 & CA-1 & EVA \\
\hline M03, M04 & ILD-2 & CA-1 & EVA \\
\hline M05, M06 & $\begin{array}{l}\text { ILD-1 } \\
\text { with Al }\end{array}$ & CA-1 & EVA \\
\hline M07 & ILD-1 & CA-1 & Polyolefin \\
\hline M08 & ILD-2 & CA-1 & Polyolefin \\
\hline M09, M10 & $\begin{array}{l}\text { ILD-1 } \\
\text { with Al }\end{array}$ & $\mathrm{CA}-1$ & Polyolefin \\
\hline $\mathrm{M} 11, \mathrm{M} 12$ & no ILD & CA-2 & EVA \\
\hline M13, M14 & no ILD & CA-2 & Polyolefin \\
\hline
\end{tabular}

\section{MODEL FOR I-V CHARACTERISTICS}

To appreciate the impact of damp heat on electrical performances, the degradation of the I$\mathrm{V}$ characteristics of these photovoltaic modules has to be determined and analyzed [16]. To plot the I-V characteristics, an explicit model known as Rauschenbach's model is used [17]. The electrical equivalent circuit which comprises one diode is represented in Fig. 2. Current I produced by the photovoltaic module is computed as a function of voltage $\mathrm{V}$ [18]. The model to plot the I$V$ curve was developed under Matlab environment. The relation between $\mathrm{I}$ and $\mathrm{V}$ is given by:

$$
I=I_{s c}\left(1-C_{1}\left(\exp \left(\frac{V}{C_{2} V_{o c}}\right)-1\right)\right)
$$


where the coefficients $\mathrm{C}_{1}$ and $\mathrm{C}_{2}$ are given by the following expressions:

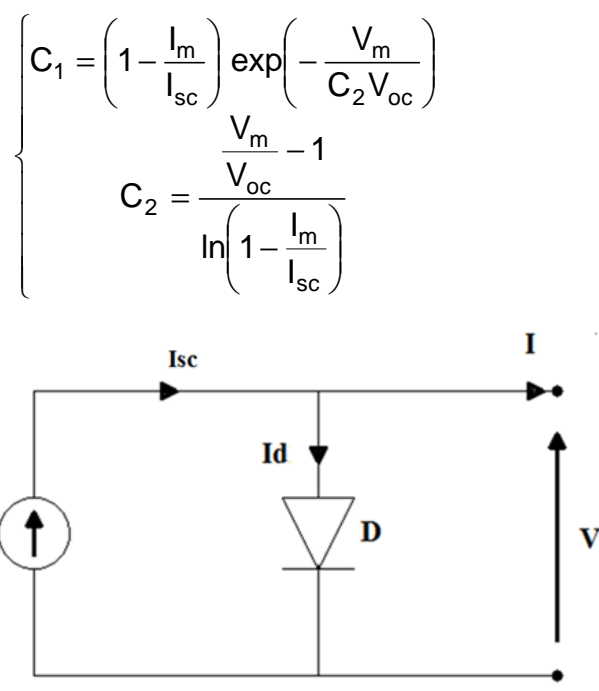

Fig. 2. Equivalent electrical circuit of a photovoltaic module

We recall that the maximum power output $\left(P_{\max }\right)$ of photovoltaic module is given by equation (3) below:

$$
P_{\max }=V_{o c} \times I_{s c} \times F F
$$

where FF is the fill factor of PV module which is an important performance indicator. It is defined as the ratio between the maximum and the nominal power as given by equation (4) [16].

$$
F F=\frac{I_{m} \times V_{m}}{V_{o c} \times I_{s c}}
$$

in which $\mathrm{I}_{\mathrm{m}}$ and $\mathrm{V}_{\mathrm{m}}$ are respectively the current and voltage at maximum power of PV module.

In order to quantify the degradation of the shortcircuit current $\left(\mathrm{I}_{\mathrm{sc}}\right)$, the open-circuit voltage $\left(\mathrm{V}_{\mathrm{oc}}\right)$, the maximum power output $\left(P_{\max }\right)$ and the fill factor (FF) of the PV module, measured standardized values are compared to the ones of the reference given by the datasheet of PV module. The relative difference $\Delta \mathrm{X}$ in percentage quantifies the degradation of one considered parameter. It can be expressed in the following form [19]:

$$
\Delta \mathrm{X}(\%)=\left(1-\frac{\mathrm{X}}{\mathrm{X}_{0}}\right) \times 100
$$

where in our case $X=\left[I_{s c}, V_{o c}, P_{\max }, F F\right]$ after degradation and $\mathrm{X}_{0}=\left[\mathrm{I}_{\mathrm{sc} 0}, \mathrm{~V}_{\mathrm{oc} 0}, \mathrm{P}_{\max 0}, \quad \mathrm{FF}_{0}\right]$ represents the reference values of the parameters given by the manufacturer in standard test conditions (STC).

\section{RESULTS AND DISCUSSION}

The following section discusses the results of I-V characteristic evolutions for all the modules M01M14 (Fig. 3) in Standard Test Conditions (STC) and the accelerated aging effect on the maximum power (Fig. 4). Initial measured values are given in Table 2. Degradations of electrical parameters are shown in Table 3. Comparison of damp heat effects is effectuated for the different photovoltaic modules and testing failure is analyzed.

Table 2. Results of I-V measurements under test conditions at $t=0$

\begin{tabular}{lllllll}
\hline Module code & $\mathbf{P}_{\mathbf{m a x}}[\mathbf{W}]$ & $\mathbf{I}_{\mathbf{s c 0}}[\mathbf{A}]$ & $\mathbf{I}_{\mathbf{m} 0}[\mathbf{A}]$ & $\mathbf{V}_{\text {oco }}[\mathbf{V}]$ & $\mathbf{V}_{\mathbf{m o}}[\mathbf{V}]$ & $\mathbf{F F}_{\mathbf{0}}[\%]$ \\
\hline M01 & 240.78 & 8.51 & 7.92 & 37.52 & 30.40 & 75.39 \\
M02 & 242.19 & 8.53 & 7.99 & 37.65 & 30.31 & 75.40 \\
M03 & 243.34 & 8.52 & 7.95 & 37.67 & 30.60 & 75.82 \\
M04 & 243.20 & 8.52 & 8.03 & 37.68 & 30.30 & 75.77 \\
M05 & 242.04 & 8.53 & 7.96 & 37.73 & 30.40 & 75.18 \\
M06 & 244.63 & 8.53 & 8.03 & 37.81 & 30.47 & 75.83 \\
M07 & 242.85 & 8.54 & 7.95 & 37.40 & 30.54 & 76.07 \\
M08 & 244.71 & 8.56 & 8.04 & 37.52 & 30.45 & 76.21 \\
M09 & 244.97 & 8.57 & 8.03 & 37.65 & 30.51 & 75.94 \\
M10 & 244.24 & 8.55 & 8.03 & 37.56 & 30.40 & 76.02 \\
M11 & 243.36 & 8.55 & 8.00 & 37.70 & 30.40 & 75.49 \\
M12 & 245.38 & 8.56 & 8.08 & 37.78 & 30.38 & 75.86 \\
M13 & 247.53 & 8.57 & 8.12 & 37.72 & 30.50 & 76.52 \\
M14 & 247.68 & 8.60 & 8.04 & 37.74 & 30.79 & 76.33 \\
\hline
\end{tabular}




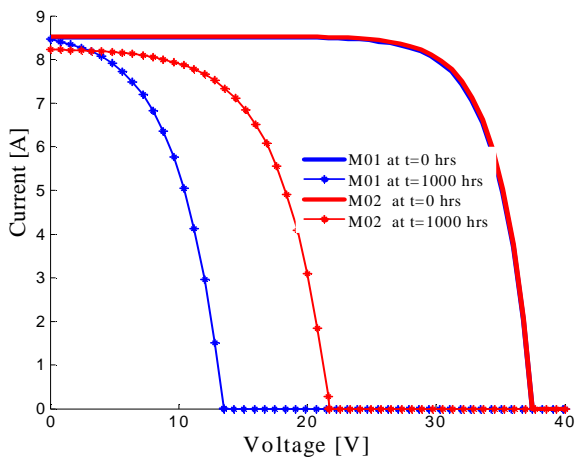

(a) M01 and M02 with ILD-1

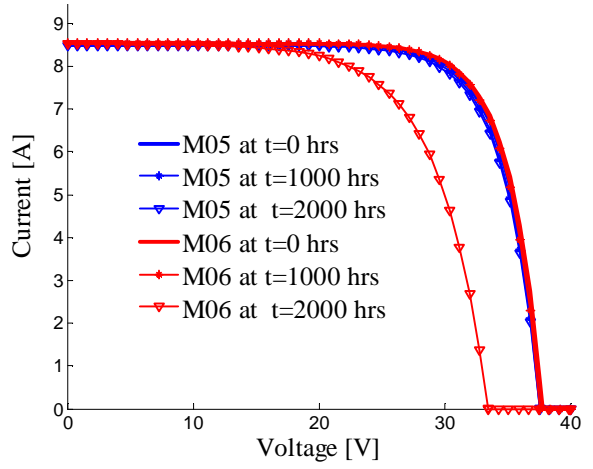

(c) M05 and M06 with EVA

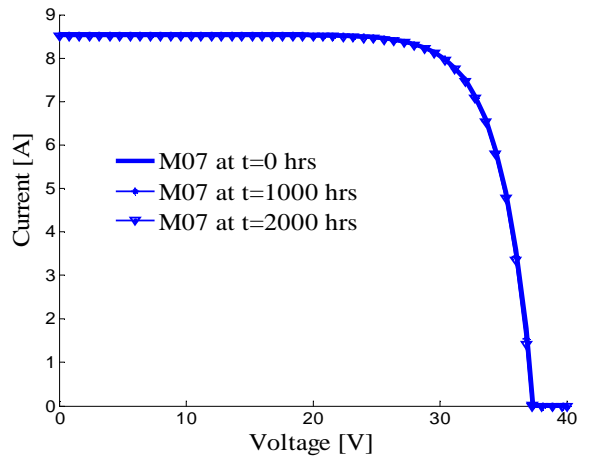

(e) M07 with ILD-1

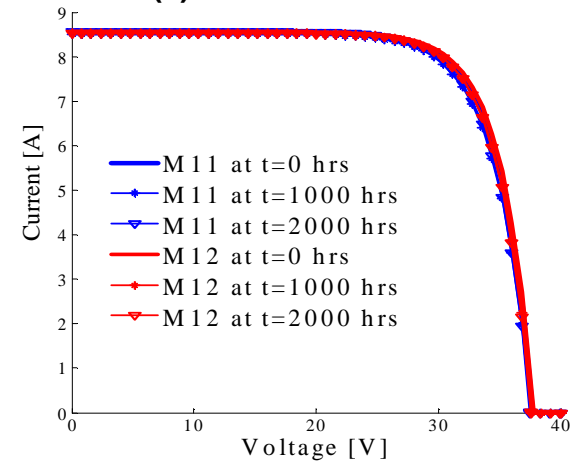

(g) M11 and M12 with EVA

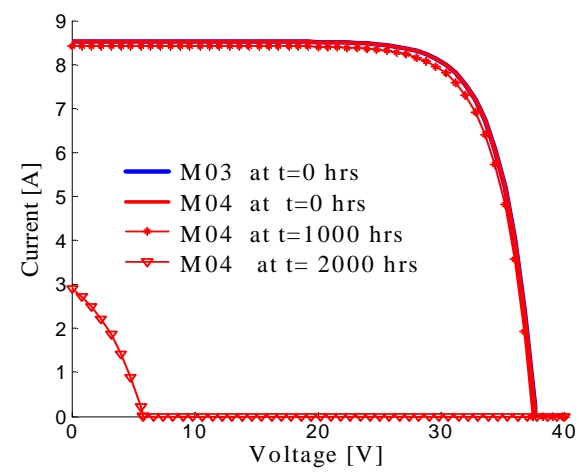

(b) M03 and M04 with ILD-2

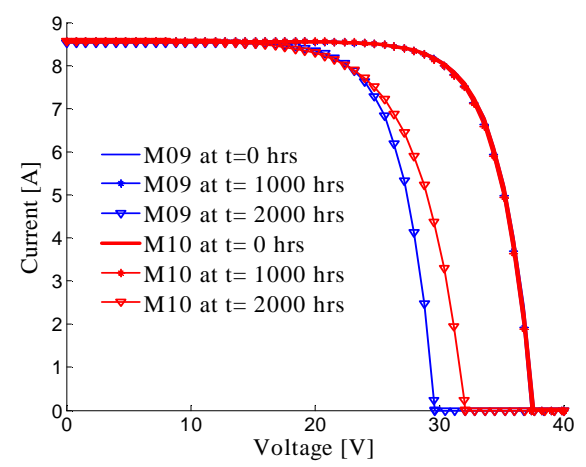

(d) M09 and M10 with polyolefin

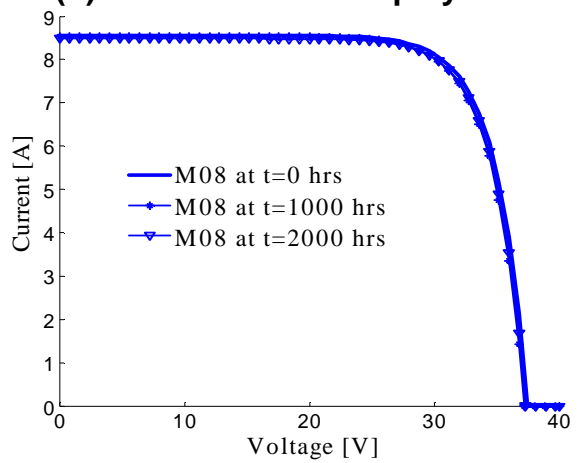

(f) M08 with ILD-2

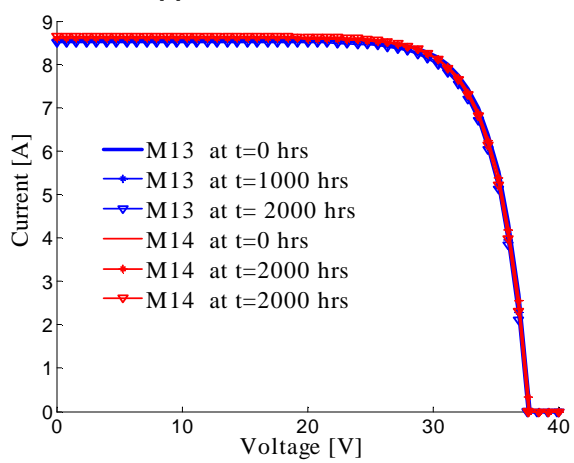

(h) M13 and M14 with polyolefin

Fig. 3. I-V characteristics for modules M01-M14 after 0, 1000 and 2000 hours under DH exposure $85^{\circ} \mathrm{C} / 85 \%$ rh 


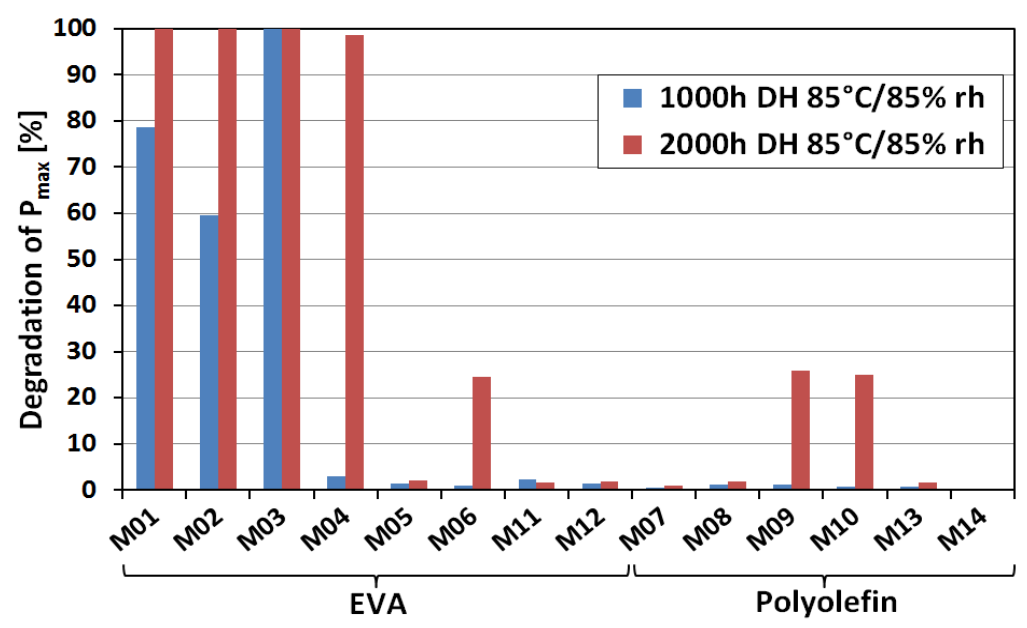

(a) Encapsulant

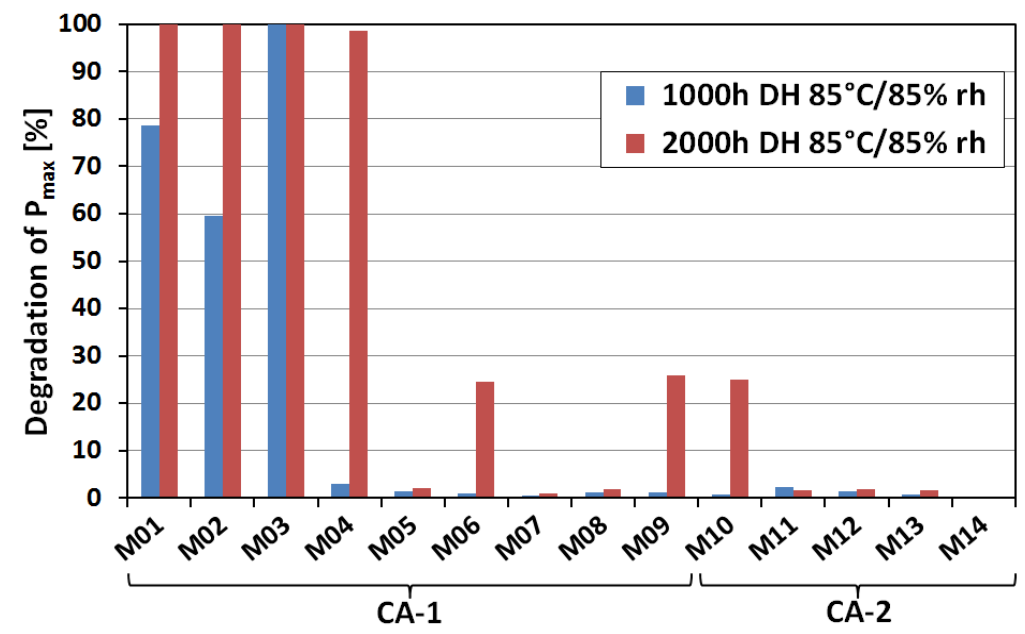

(b) Conductive adhesive

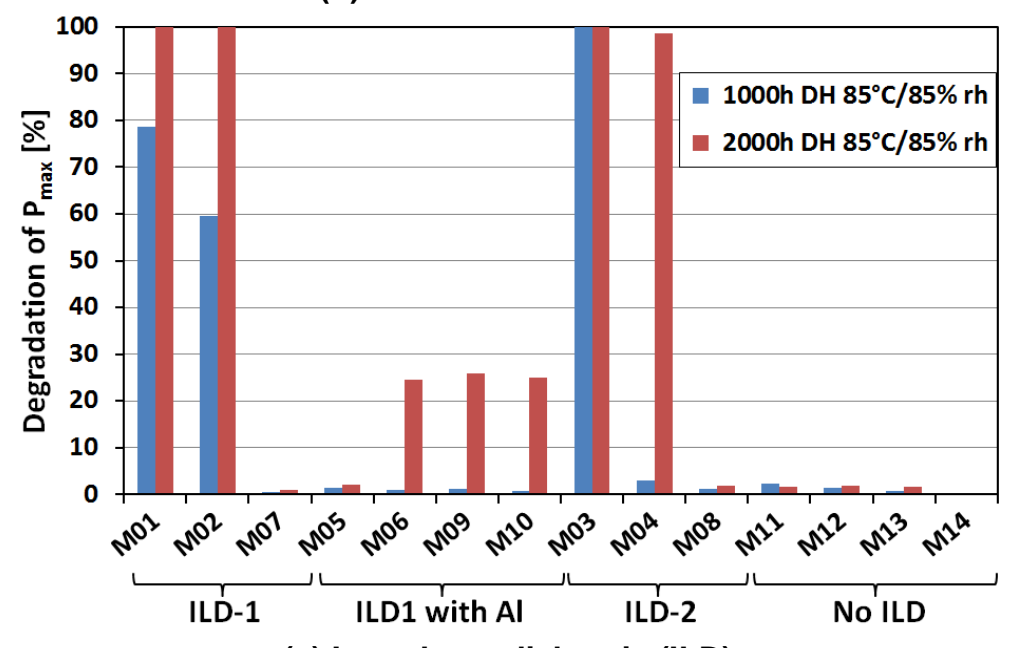

(c) Inner layer dielectric (ILD)

Fig. 4. Degradation for the maximum power $\left(P_{\max }\right)$ for the fourteen MWT photovoltaic modules under damp heat exposure 
Table 3. Comparison of electrical parameter evolutions

\begin{tabular}{|c|c|c|c|c|c|c|c|c|c|}
\hline \multirow[t]{3}{*}{ Module } & \multirow{3}{*}{$\begin{array}{l}\text { Composition } \\
\text { DH time }\end{array}$} & \multicolumn{8}{|c|}{ Degradation [\%] } \\
\hline & & \multicolumn{2}{|c|}{$I_{\text {sc }}$} & \multicolumn{2}{|c|}{$V_{o c}$} & \multicolumn{2}{|c|}{ FF } & \multicolumn{2}{|c|}{$\mathbf{P}_{\max }$} \\
\hline & & $1000 \mathrm{~h}$ & $2000 \mathrm{~h}$ & $1000 \mathrm{~h}$ & $2000 \mathrm{~h}$ & $1000 \mathrm{~h}$ & $2000 \mathrm{~h}$ & $1000 \mathrm{~h}$ & $2000 \mathrm{~h}$ \\
\hline M01 & ILD1, CA1, EVA & 0.59 & 100 & 64.3 & 100 & 39.85 & 100 & 78.6 & 100 \\
\hline M02 & & 3.52 & 100 & 42.31 & 100 & 27.21 & 100 & 59.5 & 100 \\
\hline M03 & ILD2, CA1, EVA & 100 & 100 & 100 & 100 & 100 & 100 & 100 & 100 \\
\hline M04 & & 1.2 & 65.4 & 0.45 & 87.97 & 1.24 & 70.87 & 3 & 98.7 \\
\hline M05 & ILD1 with Al, CA1, EVA & 0.12 & 0.6 & 0.37 & 0.45 & 0.78 & 1 & 1.3 & 2.03 \\
\hline M06 & & -0.12 & 0.23 & 0.53 & 11.43 & 0.59 & 14.72 & 1 & 24.6 \\
\hline M07 & ILD1, CA1, polyolefin & 0.12 & 0.35 & 0.27 & 0.37 & 0.12 & 0.37 & 0.5 & 1.06 \\
\hline M08 & ILD2, CA1, polyolefin & 0.35 & 0.93 & 0.67 & 0.45 & 0.17 & 0.43 & 1.2 & 1.8 \\
\hline M09 & ILD1 with AI, CA1, & 0.12 & 0.47 & 0.5 & 21.2 & 0.59 & 5.4 & 1.2 & 25.77 \\
\hline M10 & polyolefin & -0.23 & -0.12 & 0.29 & 14.54 & 0.61 & 12.3 & 0.7 & 25 \\
\hline M11 & No ILD, CA2, EVA & 0.47 & -0.12 & 0.4 & 0.5 & 1.46 & 1.15 & 2.4 & 1.54 \\
\hline M12 & & 0.23 & 0.47 & 0.45 & 0.58 & 0.66 & 0.84 & 1.3 & 1.93 \\
\hline M13 & No ILD, CA2, polyolefin & 0.002 & 0.7 & 0.32 & 0.53 & 0.24 & 0.29 & 0.8 & 1.6 \\
\hline M14 & & 0 & -0.47 & 0.21 & 0.42 & 0.1 & 0.34 & 0.3 & 0.3 \\
\hline
\end{tabular}

\subsection{Modules with Same EVA but with Different Backsheet Foils (ILD-1, ILD-2)}

The I-V characteristics and the degradation of $\mathrm{I}_{\mathrm{sc}}$, $\mathrm{V}_{\mathrm{oc}}$, FF and $\mathrm{P}_{\max }$ of both modules M01 and M02 with the same ILD-1 are illustrated respectively in Figs. $3 \mathrm{a}, 4$ and Table 3 . There is a strong decrease of the I-V characteristics with degradation for $\mathrm{V}_{\mathrm{OC}}$ of $64.3 \%$ and $42.3 \%$. A large drop in FF and $\mathrm{P}_{\max }$ of respectively $39.8 \%$ and $27.2 \%$, and, $78.6 \%$ and $59.5 \%$ is observed and slight degradation in $\mathrm{I}_{\mathrm{sc}}$ of $0.6 \%$ and $3.5 \%$ after 1000 hours of $\mathrm{DH}$ test.

The I-V characteristics and degradation of $\mathrm{I}_{\mathrm{sc}}$, $\mathrm{V}_{\mathrm{oc}}, \mathrm{FF}$ and $\mathrm{P}_{\max }$ of modules M03 and M04 with the same ILD-2 are illustrated respectively in Figs. 3b, 4 and Table 3. No degradations were observed for the module M04, but the module M03 presented some defects on the back side, which were visible already before lamination and were still recognizable after 1000 hours of DH test. Module M03 failed between initial time and 1000 hours of $\mathrm{DH}$ test.

After 2000 hours of damp heat testing, both modules M01 and M02 were deteriorated due to delamination at the ILD-1/Cu interface (Fig. 5). Delamination, which is the most important cause of module failure, occurs when there is moisture ingress in the EVA encapsulant. Delamination is caused by adhesive fracture at ILD/Cu interface (green ILD remains attached to EVA). This puts stress on interconnection and could cause failure. Module M04 is slightly more degraded with reduced $\mathrm{I}_{\mathrm{sc}}, \mathrm{V}_{\mathrm{oc}}, \mathrm{FF}$ and $\mathrm{P}_{\max }$ of respectively $65.4 \%, 87.0 \%, 70.9 \%$ and $98.7 \%$ (Figs. $3 b, 4$ and Table 3). It appears that the combined effect of moisture and EVA causes a weakening of the adhesion strength at the interface between copper foil and ILD which favors delamination. This observation is in agreement with the previous study of Guichoux et al. [20] where it is pointed out that delamination between encapsulant and ILD is caused by the presence of moisture and ultimately results in module failure. Eerenstein et al. reported that these MWT modules successfully passed the DH test of 2000 hours and also the wet leakage test [12]. However, a few modules failed after 1000 hours of $\mathrm{DH}$ test. A failure analysis based on dark lockin thermography (DLIT) data and the opening of the modules pointed out an interconnection failure possibly related to delamination.

\subsection{Modules with Same EVA and with ILD-1 with Al}

The I-V characteristics and the degradation rates of $I_{s c}, V_{o c}, P_{\max }$ and FF for modules M05 and M06 having the same encapsulant (EVA) and ILD-1 with Al are illustrated in Figs. 3c, 4 and Table 3.

The initial I-V characteristic remains stable after 1000 hours of $\mathrm{DH}$ test. After 2000 hours of damp heat testing, the module M05 is still very stable due to the presence of a moisture blocking $\mathrm{Al}$ layer integrated in the backsheet [6]. However, module M06 presents a drop in $\mathrm{V}_{\mathrm{oc}}$ of $11.43 \%$ which induces decrease of $\mathrm{FF}$ and $\mathrm{P}_{\max }$ by respectively $14.7 \%$ and $24.6 \%$. No change was observed for $\mathrm{I}_{\mathrm{sc}}$. Visual inspection shows that high humidity in the test chamber provokes the apparition of delamination patches visible on the back side of the module. Cracks can be seen in 


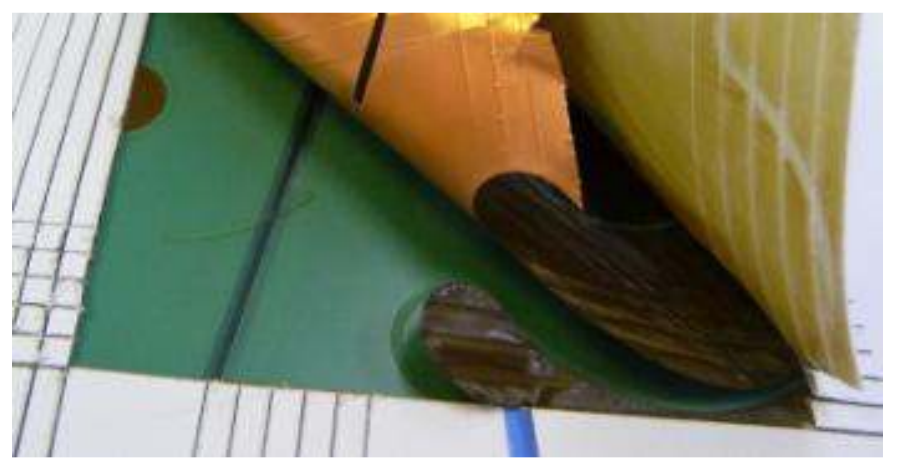

Fig. 5. Delamination area in module M01 after 2000 hours of damp heat exposure $\left(85^{\circ} \mathrm{C} / 85^{\circ} \% \mathrm{rh}\right)$

Al at overlap with Ag. Module M06 has one cracked photovoltaic cell.

\subsection{Modules with Same Polyolefin and with ILD-1 with Al}

The I-V characteristics and the degradation rates of $\mathrm{I}_{\mathrm{sc}}, \mathrm{V}_{\mathrm{oc}}, \mathrm{FF}$ and $\mathrm{P}_{\max }$ for modules M09 and M10 having the same encapsulant (polyolefin) and with ILD-1 with Al are displayed in Figs. 3d, 4 and Table 3.

The I-V characteristics are stable during the entire damp heat exposure of 1000 hours. After 2000 hours of damp heat testing, both M09 and M10 modules have a fall in $\mathrm{V}_{\text {oc }}$ of $21.2 \%$ and $14.5 \%$, which induces a decrease of $\mathrm{FF}$ and $\mathrm{P}_{\max }$ of respectively $5.4 \%$ and $12.3 \%$, and, $25.8 \%$ and $25.0 \%$, which implies a raise of the series resistance. For $\mathrm{I}_{\mathrm{sc}}$, no degradation was observed. Hence, the alteration is reduced with EVA for long times in this case. Visual inspection shows bubbles accumulated at the backsheet.

\subsection{Modules with Same Polyolefin but with Different Backsheet Foils (ILD-1, ILD-2)}

Results for modules M07 and M08, which have the same polyolefin encapsulant but two foils with different interlayer dielectric (ILD-1 and ILD2) are compared. The I-V characteristics and the degradation of $\mathrm{I}_{\mathrm{sc}}, \mathrm{V}_{\mathrm{oc}}, \mathrm{FF}$ and $\mathrm{P}_{\max }$ for both modules M07 and M08 with the same encapsulant (polyolefin) are displayed in Fig. 3(e), Figs. 3f, 4 and Table 3.

The I-V characteristics remain unmodified after 1000 hours of DH test. Both modules M07 and M08 are also very stable after 2000 hours of damp heat testing. These results show that polyolefin encapsulant in combination with moisture does not induce delamination of the backsheet. Similar results were observed for thermoplastic encapsulants elsewhere [6].

\subsection{Modules with Different Encapsulants (EVA, Polyolefin) without ILD}

Comparison is performed here between both modules M11 and M12 which have the same EVA and both modules M13 and M14 with the same polyolefin but without interlayer dielectric (ILD). The I-V characteristics and the degradation rates of $I_{s c}, V_{o c}, F F$ and $P_{\max }$ of modules M11, M12, M13 and M14 are depicted in Figs. 3g, 3h, 4 and Table 3.

I-V characteristics remain unchanged after 1000 hours of DH test. After 2000 hours of damp heat testing, FF and $\mathrm{P}_{\max }$ are slightly degraded by $1.2 \%$ and $0.8 \%$, and, $1.5 \%$ and $1.9 \%$ for modules M11 and M12 respectively.

I-V characteristics for both modules $\mathrm{M} 13$ and M14 stay very stable up to 2000 hours. Maximum power is slightly degraded by respectively $1.6 \%$ and $0.3 \%$ which is under $2 \%$. This degradation is much less severe than for the other cases. There is no failure and the stability is the best. So, the elimination of both ILD and the silver contact dots related to delamination at the ILD/Cu interface permits an optimal stability of the MWT module. Hence, this packaging should be selected.

\subsection{Maximum Power Degradation Comparison}

The found maximum power degradations under damp heat are represented in Fig. 4 according to encapsulant (a), conductive adhesive (b) and ILD (c). The I-V characteristics remain quasi unmodified after 1000 hours for modules M04 to M14 since no major diminutions were observed for electrical quantities as shown in Figs. $3 \mathrm{~b}$ to $3 \mathrm{~h}$ 
and 4. Degradation of $P_{\max }$ remains under $5 \%$ after 1000 hours of DH test (see Table 3), as requested by the IEC 61215 standard. The photovoltaic modules have a better stability with the polyolefin encapsulant. Its maximum power decrease starts when approaching 2000 hours of test. Modules having the conductive adhesive CA-2 remain very stable. ILD-1 gives altered electrical characteristics after 1000 hours and total failure after 2000 hours. The adjunction of $\mathrm{Al}$ to ILD provides a better stability, even though maximum power gets affected after 2000 hours. The best results are obtained when there is no ILD. Thus, the optimal configuration as afore mentioned is polyolefin encapsulant, conductive adhesive (CA-2) and no ILD.

\section{CONCLUSION}

Back-contact MWT modules with different packaging were tested under damp heat conditions. Results reveal that modules which combine conductive backsheet foil with two types of ILD and EVA showed higher degradation rates. Moisture ingress into the module and its interaction with EVA causes a weakening of adhesion strength at the ILD/Cu interface and could cause delamination between Ag-plated contacts applied to copper and conductive adhesive. Replacing EVA with an alternative encapsulant (e.g. a polyolefin) and/or use of a moisture barrier in the backsheet improves the module stability under damp heat. However, removal of ILD is the most interesting approach and is currently adopted by foil manufacturers. Importantly, the modules built with ILD-free backsheet and either polyolefin encapsulant or EVA showed respectively only $0.3 \%$ and $1.6 \%$ maximum power loss after 2000 hours of damp heat which is well below the requirement of the IEC 61215 standard.

\section{ACKNOWLEDGEMENTS}

The authors thank J.A.J. Peters and K.M. Broek for their technical assistance and I.J. Bennett for useful discussions all three from ECN, as also Mrs. Wilhelmina Logerais, a native speaker, for her help with English.

\section{COMPETING INTERESTS}

Authors have declared that no competing interests exist.

\section{REFERENCES}

1. Westin PO, Neretnieks P, Edoff M. Damp heat degradation of CIGS - Based PV modules. $21^{\text {st }}$ European Photovoltaic Solar Energy Conference. Germany; 2006.

2. International Electrotechnical Commission Crystalline silicon terrestrial photovoltaic (PV) module - Design qualification and type approval. IEC 61215. $2^{\text {nd }}$ ed; 2005.

3. Bennett IJ, Tjengdrawira $C$, Mewe AA, Lamers MWPW, de Jong PC, Weeber AW. World record module efficiency for large and thin mc-Si MWT cells. Proceedings of the $24^{\text {th }}$ European Photovoltaic Solar Energy Conference and Exhibition. Hamburg. Germany; 2009.

4. Spath $M$, de Jong PC, Bennett IJ, Visser TP, Bakker J. A novel Module assembly line using backcontact solar cells. Proceedings of $33^{\text {rd }}$ IEEE Photovoltaic Specialist Conference. San Diego. USA; 2008.

5. Tjengdrawira C, Lamers MWPW, Bennett IJ, de Jong PC. World first $17 \%$ efficient multi-crystalline silicon module. $35^{\text {th }}$ IEEE Photovoltaic Specialist Conference; 2010.

6. Rosca V, Bennett IJ, Eerenstein W. Systematic reliability studies of backcontact photovoltaic modules. Proceedings of the SPIE. San Diego. California. USA; 2012.

7. Meyer K, Menkoe M, Krokoszinski HJ, Wutherich T, Dupke M, Jesswein R, Roth T. MWT cells with Al-BSF on $\mathrm{Cz}$ silicon with efficiencies up to $19.4 \%$. Proceedings of the $26^{\text {th }}$ EUPVSEC. Hamburg. Germany. 2011;984-988.

8. Meyer C, Ramspeck K, Zell M, Moschner J, Metz A. Efficiency delta between MWT and $\mathrm{H}$-pattern cells: Calibration issues and hybrid reference cell as solution. Proceedings of the $26^{\text {th }}$ EUPVSEC. Hamburg. Germany. 2011;1063-1067.

9. Augustin $L M$, van den Donker $M N$, Scholten $H$, Zell $M$, Claussen W, Van Straaten B, Copetti C, Fleuster M, Feldhaus $M$, Schier D, Fliedner $U$, Wangemann K. Mass Production and Field Performance of Durable Metal-WrapThrough Integrated Back Contact Foil Based "Sunweb" Modules. Proceedings of the $26^{\text {th }}$ EUPVSEC. Hamburg. Germany. 2011;3113-3116.

10. Bultman JH, Brieko MW, Burgers AR, Hoornstra J, Tip AC, Weeber AW. Interconnection through vias for improved effiency and easy module manufacturing of crystalline silicon solar cells. Solar Energy Materials \& Solar Cells. 2001;65:339-245. 
11. Eerenstein W, Bennett IJ, Spath M, Dekker NJJ, Rosca V. Back contact module technology. China PV Technology International Conference; 2012.

12. Eerenstein $\mathrm{W}$, Bennett IJ, Veldman D, VisserT, Brockholz B, De Jong PC, Copetti $\mathrm{CA}$, Wijnen P. Climate chamber test results of MWT back contact modules. European Photovoltaic Solar Energy Conference and Exhibition. $5^{\text {th }}$ World Conference on Photovoltaic Energy Conversion Valencia. Spain; 2010.

13. Lamers MWPE, Tjengdrawira C, Koppes $M$, Bennett IJ, Bende EE, Visser TP, Kossen E, Brockholz B, Mewe AA, Romijn IG, Sauar E, Carnel L, Julsrud S, Naas T, de Jong PC, Weeber AW. 17.9\% Metal-wrap-through mc-Si cells resulting in module efficiency of 17.0. Progress in Photovoltaics. 2011;20(1):62-73.

14. Bennett IJ, Bende EE, Goris MJAA, Eerenstein W. An overview of developments in foil-based back- contact modules. $29^{\text {th }}$ European Photovoltaic Solar Energy Conference and Exhibition. Amsterdam. The Netherlands. 22-26 September; 2014.

15. Bennett IJ, Goris MJAA, Eerenstein W. Reducing the cost of MWT module technology based on conductive backsheet foils. $28^{\text {th }}$ European Photovoltaic Solar Energy Conference and Exhibition. 30 September - 4 October 2013. Paris. France.

16. Skoplaki E, Plyvos JA. On the temperature dependance of photovoltaic module electrical performance: A review of efficiency / power correlations, Solar Energy. 2009;83:614-624.

17. Sadok M, Mehdaoui. A. Outdoor testing of photovoltaic arrays in the Saharan region. Renewable Energy. 2008;33:2516-2524.

18. Lasnier F, Sivoththaman S. Photovoltaic system sizing and performance by the comparison of demand and expected radiations. International Journal of Solar Energy. 1990;9:65-76.

19. Ndiaye A, Kébé CMF, Charki A, Ndiaye PA, Sambou V, Kobi A. Degradation evaluation of crystalline-silicon photovoltaic modules after a few operation years in a tropical environment. Solar Energy. 2004; 103:70-77.

20. Guichoux M, Tjengdrawira C, Veldman D, de Jong PC. Impact of materials on back-contact module reliability. $35^{\text {th }}$ IEEE Photovoltaic Specialist Conference. Honolulu. Hawaii. USA; 2010.

(C) 2016 Bandou et al.; This is an Open Access article distributed under the terms of the Creative Commons Attribution License (http://creativecommons.org/licenses/by/4.0), which permits unrestricted use, distribution, and reproduction in any medium, provided the original work is properly cited. 